\title{
Some Differences in the Microbiology of Profundal and Littoral Lake Sediments
}

\author{
By J. GWYNFRYN JONES \\ The Freshwater Biological Association, Windermere Laboratory, The Ferry House, \\ Ambleside, Cumbria LA22 OLP
}

(Received 2 October 1979)

\begin{abstract}
The microbial populations of the littoral (shallow water) and profundal (deep water) surface sediments of Blelham Tarn and the South Basin of Windermere were examined. Microbial numbers (direct counts), biomass (ATP) and activity (electron transport system activity, $\mathrm{CO}_{2}$ evolution and $\left[{ }^{14} \mathrm{C}\right]$ glucose mineralization) were consistently higher in the profundal zone of both lakes, the difference being greater and average values higher in the more productive Blelham Tarn. The interstitial water of the profundal sediments contained higher concentrations of available substrates (carbohydrate, protein and amino acids). There were marked differences in the particle size distribution of the sediments with a greater proportion of small particles ( $<45 \mu \mathrm{m}$ in size) in the profundal samples. The smaller particles from both sites were colonized by a larger number of bacteria and contained higher electron transport system activity per gram dry weight. There was a greater diversity of benthic animals in the littoral zone of both lakes but larger numbers of ciliated protozoa were observed in the profundal sediments.
\end{abstract}

\section{INTRODUCTION}

Most of the published work in freshwater microbiology is concerned with the plankton, although the benthic population is often larger and more active. There is also very little information on the spatial distribution of microbes in sediments, particularly in the horizontal plane. Willoughby (1961) observed differences in the populations of lower fungi in marginal and submerged sediments and later (Willoughby, 1974), after examination of benthic fungi inside and outside experimental enclosures in Blelham Tarn, concluded that some species were merely washed in, whereas others appeared to be active in the deeper sediments. Members of the Saprolegniales, for example, were observed to be more active in the marginal than the deep water sediments (Willoughby, 1965; Dick, 1971). There have been no comparable studies on bacteria, with the exception of the work of Willoughby (1969), who demonstrated that the distribution of actinomycetes differed from that of some lower fungi in that numbers were highest in the deep water zone. Recent investigations of freshwater sediments in the English Lake District (Jones, 1979) showed differences in microbial biomass and activity related to the $E_{\mathrm{h}}$ of the sediment. During these studies differences were observed between the microbial populations of the benthos in the littoral zone (the shallow water area usually exposed to light) and the profundal zone (the deep water sediments in the hypolimnion). This paper examines these differences in more detail and attempts to provide possible explanations for them. 


\section{METHODS}

Sampling. Sediment cores (area $38 \mathrm{~cm}^{2}$ ) were taken from the littoral and profundal zones of Windermere (South Basin), Grasmere and Blelham Tarn with a Jenkin surface mud corer as described by Jones (1979). The rationale of the sub-sampling procedure (i.e. the depth of sediment which was removed from each core) is explained in the first paragraph of Results and Discussion.

Direct counts of bacteria. Epifluorescence counts were performed according to the procedure of Jones \& Simon $(1975 \mathrm{a})$. The fluorochrome used was acridine orange at a final concentration of $10 \mathrm{mg} \mathrm{l}^{-1}$. The sediment samples were diluted to $10^{-3}$ with membrane-filtered water and treated in an ultrasonic disintegrator at an amplitude of $12 \mu \mathrm{m}$ for $30 \mathrm{~s}$ to disperse clumps.

ATP content. A sensitive modification of the luciferin-luciferase procedure (Jones \& Simon, 1977) was used to analyse ATP. The sediment was diluted to $10^{-3}$ immediately before extraction in boiling Tris buffer at $\mathrm{pH} 7 \cdot 8$. Internal standards were analysed with each sample.

Electron transport system (ETS) activity. This assay was used as a general measure of microbial energy metabolism. The method used was that of Owens \& King (1975) as modified by Jones \& Simon (1979) to ensure optimum conditions for extraction of enzymes from freshwater sediments.

Measurement of carbon mineralization. The accumulation of $\mathrm{CO}_{2}$ when sediment samples were incubated was taken as a measure of the microbial mineralization of organic carbon. Sediment samples were incubated in polypropylene syringes for $24 \mathrm{~h}$. A head-space of purified nitrogen, equal in volume to the sediment, was then introduced, and $0.04 \mathrm{vol} .1 .5 \mathrm{M}_{-} \mathrm{H}_{2} \mathrm{SO}_{4}$ was injected through the piston head of each syringe. The sample was shaken vigorously and the gas in the head-space was analysed on a gas chromatograph as described by Jones \& Simon (1980).

Glucose mineralization. $\left[\mathrm{U}-{ }^{14} \mathrm{C}\right] \mathrm{Glucose}(0.05 \mu \mathrm{Ci}, 1.85 \mathrm{kBq})$ was added to each $5 \mathrm{ml}$ sample, giving a final glucose concentration of $35 \mathrm{nmol} \mathrm{1}^{-1}$. [This was of the same order as the observed natural concentrations of glucose in such samples $\left(17\right.$ to $\left.55 \mathrm{nmol} \mathrm{l}^{-1}\right)$ for which direct flux measurements of 0.3 to $0.9 \mathrm{nmol} \mathrm{l}^{-1} \mathrm{~h}^{-1}$ have been recorded (Jones \& Simon, 1975b).] The samples were incubated in sealed $50 \mathrm{ml}$ vessels (Hobbie \& Crawford, 1969) at $8.5^{\circ} \mathrm{C}$ for $1 \mathrm{~h}$ and the reaction was then stopped by the addition of $0.2 \mathrm{ml} 1.5 \mathrm{M}-\mathrm{H}_{2} \mathrm{SO}_{4}$. The evolved ${ }^{14} \mathrm{CO}_{2}$ was collected in $0.25 \mathrm{ml}$ phenethylamine which was then mixed with $10 \mathrm{ml}$ scintillation fluid [ $100 \mathrm{~g}$ naphthalene, $100 \mathrm{ml}$ water, $4 \mathrm{~g} \mathrm{2,5-diphenyloxazole} \mathrm{and} \mathrm{0.05} \mathrm{g} \mathrm{1,4-di-2-(5-phenyloxazolyl)-}$ benzene in $900 \mathrm{ml}$ 1,4-dioxan] and counted in a liquid scintillation counter; the channels ratio method was used for quench correction.

Enumeration of zoobenthos. The top $10 \mathrm{~cm}$ of sediment from each core was removed and the populations of the larger zoobenthos (chironomid larvae, Chaoborus larvae, oligochaetes, Ceratopogonidae, bivalves and larvae of mayflies, caddis flies, alder flies) were separated by wet sieving and counted. The populations of the smaller zoobenthos (tardigrades, gastrotrichs, rotifers, nematodes and ciliates) were counted in $10 \mu \mathrm{l}$ drops of a $10^{-1}$ dilution of the surface $4 \mathrm{~cm}$ of sediment, as described by Finlay et al. (1979).

$E_{\mathrm{b}}$ measurements. A bright platinum electrode was used to measure $E_{\mathrm{h}}$ in the sediment at $2 \mathrm{~mm}$ intervals as described by Jones (1979).

Dry weight and organic matter content. Sediment samples of known volume and wet weight were dried at $80^{\circ} \mathrm{C}$ overnight and then reweighed. The organic matter content of these samples, determined as loss on ignition, was obtained by heating them in a muffle furnace at $550{ }^{\circ} \mathrm{C}$ for $24 \mathrm{~h}$.

Inorganic chemistry of sediment interstitial water. Sediment samples were centrifuged at $5500 \mathrm{~g}$ for $45 \mathrm{~min}$ at $2{ }^{\circ} \mathrm{C}$. The supernatant was removed and analysed for nitrate-nitrogen, ammonia-nitrogen and soluble reactive phosphorus according to the procedures described by Mackereth et al. (1978).

Organic chemistry of sediment interstitial water. The samples were centrifuged as described above. The primary amine content of the interstitial water was determined by the fluorescamine method of Udenfriend et al. (1972) using the procedure of North (1975) for natural waters. The protein content was determined using the micro-modification (Kochert, 1978) of the Coomassie Brilliant Blue dye binding technique (Bradford, 1976). The total carbohydrate content was determined by the phenol/sulphuric acid method, as described by Kochert (1978).

Particle size distribution of the sediments. Samples of sediment were partitioned in a wet-sieve apparatus (Fritsch, Analysette). Each sample was treated for $30 \mathrm{~min}$ and the sieve stack was vibrated at a vertical amplitude of $2 \mathrm{~mm}$. The mesh sizes used were 500,250,125 and $45 \mu \mathrm{m}$ and the proportion of sediment in each size category was determined by dry weight measurements. Sub-samples were taken to determine the total counts of bacteria, ATP content and ETS activity of each particle size category.

Statistical analyses. Where possible $95 \%$ confidence limits of the variables were calculated and differences between littoral and profundal sediments were tested by application of the $t$-test to suitably transformed data. When there were insufficient data to provide information on the parent distribution of any given variable, the results were presented as means with standard deviations. 


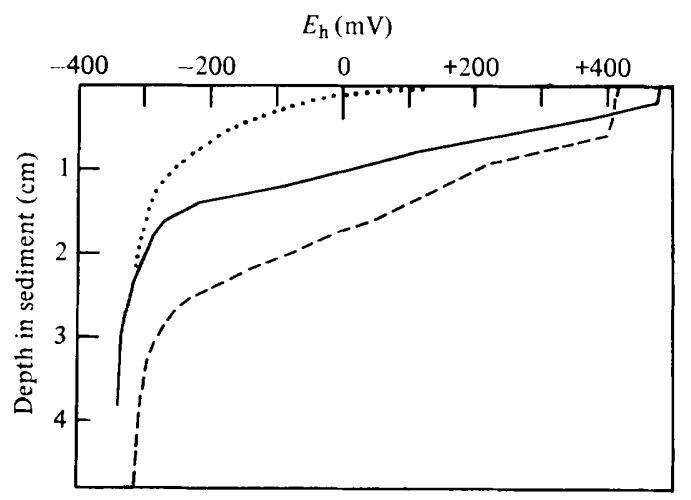

Fig. 1. $E_{\mathrm{h}}$ profiles of littoral (3 m depth, - - -) and profundal (21 $\mathrm{m}$ depth, - - ) sediments in Grasmere during January 1977. The profundal profile in July 1977 is also shown $(\cdots)$. Readings were taken at $2 \mathrm{~mm}$ intervals with a bright platinum electrode, after equilibration for $1 \mathrm{~min}$ at each depth.

Table 1. Microbial biomass, activity and numbers in the top $1 \mathrm{~cm}$ of littoral and profundal sediments in Grasmere during March 1978

$\begin{array}{lcr}\text { Littoral } & \text { Sediment type } \\ 10^{-10} \times \text { Direct counts of bacteria } \mathrm{g}^{-1} & 1 \cdot 6(0 \cdot 4)^{*} & 5 \cdot 3(2 \cdot 1) \\ \text { ATP content }\left(\mu \mathrm{g} \mathrm{g}^{-1}\right) & 10 \cdot 1(3 \cdot 7) & 14 \cdot 2(2 \cdot 9) \\ \text { ETS activity }\left(\mathrm{mg} \mathrm{O}_{2} \mathrm{~g}^{-1} \mathrm{~h}^{-1}\right) & 2 \cdot 6(0 \cdot 9) & 7 \cdot 2(1 \cdot 3) \\ \text { * Values in parentheses indicate standard deviation on five replicate sediment cores. }\end{array}$

\section{RESULTS AND DISCUSSION}

Transects of Blelham Tarn made during a previous study (Jones, 1979) had shown marked differences between littoral and profundal lake sediments. The littoral, shallow water, sediments were subjected to greater turbulence in the overlying water, and therefore the surface oxidized zone extended to a greater depth in the sediment. The $E_{\mathrm{h}}$ gradient in the profundal sediment was steeper, closer to the sediment-water interface, and moved upwards as thermal stratification and deoxygenation of the deeper waters of the hypolimnion progressed. Examples of such $E_{\mathrm{h}}$ profiles from Grasmere, a mesotrophic lake, are shown in Fig. 1. Measurements of bacterial numbers, ATP content and ETS activity in the surface $1 \mathrm{~cm}$ of sediment from these sites showed that in each case the values obtained from the profundal sediments were higher (Table 1). The differences in direct counts and ETS activity were significant at $P=0 \cdot 05$. These results were obtained with sediment sub-samples taken to a fixed depth, i.e. $1 \mathrm{~cm}$. If this sampling procedure were to be continued, particularly after thermal stratification, then samples could not be considered to be truly comparable, since there would be a greater likelihood of sampling through the $E_{\mathrm{h}}$ discontinuity layer into reducing sediments in the profundal site. This has been demonstrated to be a zone of high microbial activity (Jones, 1979). All further determinations were therefore made on the oxidizing surface sediment by taking samples not to a fixed depth, but to a given $E_{\mathrm{h}}$ value. In this instance the sediment which had an $E_{\mathrm{h}}$ value above $+250 \mathrm{mV}$ was sampled. Mortimer (1942) considered that the boundary between oxidizing and reducing conditions in freshwater sediments occurred at about $+200 \mathrm{mV}$, and since most $E_{\mathrm{h}}$ determinations can be made to an accuracy of only about $50 \mathrm{mV}$ (Whitfield, 1969) the choice of $+250 \mathrm{mV}$ to define sampling depth appeared to be reasonable. This meant, of course, that a greater depth of sediment was usually sampled in the littoral zone. Although it has been 
demonstrated that microbial activity is not necessarily always highest at the sedimentwater interface (Jones, 1979) I considered that it was necessary to confirm that microbial numbers and activity were not diluted by sampling to the greater depth in the littoral zone. Sediment cores were taken from the two zones of Blelham Tarn. The depths of the $+250 \mathrm{mV}$ $E_{\mathrm{h}}$ readings were 7 and $21 \mathrm{~mm}$, respectively, in the profundal and littoral cores. Sediment from 0 to $7 \mathrm{~mm}$ was analysed from the former whereas sediment from 0 to $7 \mathrm{~mm}$ and 0 to $21 \mathrm{~mm}$ was taken from the littoral site. The direct counts and ETS activity in the 0 to $7 \mathrm{~mm}$ and 0 to $21 \mathrm{~mm}$ zones of the littoral samples were $6 \cdot 0 \times 10^{10}$ and $7 \cdot 6 \times 10^{10}$ bacteria $\mathrm{g}^{-1}$ and 4.3 and $4.7 \mathrm{mg} \mathrm{O}_{2} \mathrm{~g}^{-1} \mathrm{~h}^{-1}$, respectively. This confirmed that dilution of the littoral microbiota did not occur by this sampling procedure and that the material taken from the two sites was comparable.

To determine whether the observed difference between littoral and profundal sediments was a general phenomenon, two lakes of differing trophic status, size and morphometry were chosen for further study. The mesotrophic South Basin of Windermere is $10 \mathrm{~km}$ long, contains approximately $113 \times 10^{6} \mathrm{~m}^{3}$ water and has a maximum depth of $42 \mathrm{~m}$. Blelham Tarn is a small eutrophic lake $0.67 \mathrm{~km}$ long, containing approximately $0.69 \times 10^{6} \mathrm{~m}^{3}$ water and has a maximum depth of $14.5 \mathrm{~m}$. During thermal stratification, consumptive processes may reduce the oxygen concentration in the deeper waters of Windermere South Basin to about $5 \mathrm{mg} \mathrm{1}^{-1}$ whereas the entire hypolimnion of Blelham Tarn becomes completely deoxygenated during the summer months.

There exists a divergence of opinion among aquatic microbiologists on whether results of sediment analyses should be presented on a dry weight or volume basis. The differences between the sediments in this study were evident regardless of the units chosen. The results are presented on a weight basis but dry weight values and sampling depths are included to allow approximate conversions to a unit volume or area basis.

The results from Windermere South Basin and Blelham Tarn confirmed the preliminary observations; whatever measurements of microbial numbers, biomass or activity were made, the results from the profundal sediments were significantly higher than those from the littoral zone (Table 2). The differences between littoral and profundal samples were greater in the smaller eutrophic tarn and were most marked in the measurements of ETS activity and $\mathrm{CO}_{2}$ evolution. The levels of activity and biomass were generally higher in the sediment of the more productive lake, which is in agreement with the observations of Jones (1971) and Jones et al. (1979). Chemical analyses of the inorganic components of the sediment interstitial water (Table 2) indicated that denitrification and/or ammonification was greater in the profundal region. The interstitial water was also analysed for potential organic substrates; higher concentrations of total carbohydrate, protein and amino acids were found in the deep water sediments. Once again the concentrations of these substrates were higher in Blelham Tarn than in Windermere. Unfortunately such analyses do not provide any information on the composition of the various nutrient pools, or on their availability to the microheterotrophs. Glucose, for example, comprises approximately $0.1 \%$ of the total carbohydrate value (Jones \& Simon, 1975b).

An analysis of the particle size distribution of the oxidizing sediments (Table 3 ) revealed a greater proportion of small particles ( $<45 \mu \mathrm{m}$ in size) in the profundal muds. The importance of surfaces to microbes in aqueous systems has long been recognized (ZoBell, 1943) and solid-liquid interfaces have, more recently, been the subject of more detailed investigation (Marshall, 1976). Hargrave (1972) demonstrated an inverse relationship between the size of sediment particles and oxygen uptake in aerobic sediments, and therefore, based on particle size distribution alone, one might expect greater activity in the profundal muds. Direct counts of bacteria attached to the various size fractions (Table 3) showed that, in most cases, larger numbers (on a dry weight basis) were obtained on the smaller particles, the exception being the littoral samples from Blelham Tarn. Whereas it could be argued that any bacteria found associated with a given particle size range after the wet sieving procedure 
Table 2. Comparison of littoral and profundal oxidizing sediments from Blelham Tarn and the South Basin of Windermere in April 1979

\begin{tabular}{|c|c|c|c|c|}
\hline & \multicolumn{2}{|c|}{ Windermere (South Basin) } & \multicolumn{2}{|c|}{ Blelham Tarn } \\
\hline & Littoral & Profundal & Littoral & Profundal \\
\hline $10^{-10} \times$ Direct counts of bacteria $\mathrm{g}^{-1}$ & $2 \cdot 9 \pm 0 \cdot 3^{*}$ & $3 \cdot 4 \pm 0 \cdot 3$ & $2 \cdot 8 \pm 0 \cdot 3$ & $11 \cdot 9 \pm 1 \cdot 2$ \\
\hline ETS activity $\left(\mathrm{mg} \mathrm{O}_{2} \mathrm{~g}^{-1} \mathrm{~h}^{-1}\right) \dagger$ & 0.9 & $3 \cdot 1$ & $3 \cdot 8$ & $18 \cdot 3$ \\
\hline ATP content $\left(\mu \mathbf{g ~ g ~}^{-1}\right) \ddagger$ & $4 \cdot 61$ & $10 \cdot 21$ & $18 \cdot 4$ & $56 \cdot 0$ \\
\hline $\mathrm{CO}_{2}$ evolution $\left(\mu \mathrm{mol} \mathrm{g}^{-1} \mathrm{~d}^{-1}\right)$ & $7 \cdot 4(0 \cdot 4) \S$ & $13 \cdot 2(2 \cdot 4)$ & $4 \cdot 5(0 \cdot 3)$ & $28 \cdot 2(5 \cdot 1)$ \\
\hline Glucose mineralization (d.p.m. $\mathrm{g}^{-1} \mathrm{~h}^{-1}$ ) & $19400(1050)$ & $32800(4720)$ & $27940(1080)$ & $98540(8595)$ \\
\hline Percentage conversion to ${ }^{14} \mathrm{CO}_{2}$ & $17 \cdot 1(3 \cdot 4)$ & $18 \cdot 4(4 \cdot 6)$ & $14 \cdot 5(2 \cdot 2)$ & $19 \cdot 5(3 \cdot 5)$ \\
\hline Depth of $E_{\mathrm{h}}+250 \mathrm{mV}(\mathrm{mm})$ & 29 & 21 & 36 & 12 \\
\hline Dry weight $(\%)$ & $13 \cdot 8$ & $9 \cdot 3$ & $14 \cdot 2$ & $5 \cdot 2$ \\
\hline Ammonia-nitrogen $\left(\mu \mathrm{g} \mathrm{l}^{-1}\right)$ & 18 & 181 & 51 & 550 \\
\hline Nitrate-nitrogen $\left(\mu \mathrm{g} \mathrm{1}^{-1}\right)$ & 363 & 17 & 131 & 29 \\
\hline Soluble reactive phosphorus $\left(\mu \mathrm{g} \mathrm{l}^{-1}\right)$ & 30 & 121 & $12 \cdot 2$ & $6 \cdot 5$ \\
\hline Total carbohydrate $\left(\mathrm{mg} \mathrm{l}^{-1}\right)$ & $2 \cdot 5$ & $4 \cdot 2$ & $9 \cdot 8$ & $39 \cdot 0$ \\
\hline Protein $\left(\mathrm{mg} \mathrm{l}^{-1}\right)$ & $0 \cdot 40(0 \cdot 2)$ & $0.56(0.21)$ & $0 \cdot 44(0 \cdot 17)$ & $3 \cdot 57(2 \cdot 78)$ \\
\hline Amino-nitrogen ( $\mu \mathrm{M}$ glycine equiv.) & $1 \cdot 2$ & $1 \cdot 3$ & $6 \cdot 6$ & $38 \cdot 0$ \\
\hline
\end{tabular}

Table 3. Particle size distribution of littoral and profundal oxidizing sediments from Blelham Tarn and the South Basin of Windermere in April 1979

\begin{tabular}{|c|c|c|c|c|}
\hline \multirow{2}{*}{$\begin{array}{l}\text { Partical size } \\
\text { range }(\mu \mathrm{m})\end{array}$} & \multicolumn{2}{|c|}{ W indermere (South Basin) } & \multicolumn{2}{|c|}{ Blelham Tarn } \\
\hline & Littoral & Profundal & Littoral & Profundal \\
\hline & \multicolumn{4}{|c|}{ Dry weight $(\%)$} \\
\hline $500-250$ & $4(27)^{*}$ & $4(14)$ & $8(37)$ & $1(21)$ \\
\hline $250-125$ & $18(20)$ & $6(18)$ & $28(31)$ & $8(35)$ \\
\hline $125-45$ & $41(17)$ & 35 (19) & $31(24)$ & $30(33)$ \\
\hline \multirow[t]{2}{*}{$<45$} & 37 (13) & $54(18)$ & $33(18)$ & $60(27)$ \\
\hline & \multicolumn{4}{|c|}{$10^{-10} \times$ Direct counts of bacteria $\mathrm{g}^{-1}$} \\
\hline $500-250$ & $1 \cdot 8$ & $5 \cdot 3$ & $6 \cdot 0$ & $7 \cdot 6$ \\
\hline $250-125$ & $4 \cdot 0$ & $8 \cdot 8$ & $7 \cdot 9$ & $9 \cdot 9$ \\
\hline $125-45$ & $4 \cdot 5$ & $9 \cdot 9$ & $8 \cdot 5$ & $27 \cdot 0$ \\
\hline$<45$ & $11 \cdot 6$ & $13 \cdot 3$ & $1 \cdot 4$ & $60 \cdot 0$ \\
\hline
\end{tabular}

* Values in parentheses indicate the organic content of each fraction, determined by loss on ignition, expressed as a percentage of the dry weight.

must be firmly attached to those particles, it was more difficult to measure activity and biomass in size-fractionated sediments because organisms were likely to be stressed during the manipulations. Although several attempts were made to analyse ATP and ETS activity in size-fractionated samples, acceptable results were achieved on only two occasions. This was not surprising since concentrations of ATP might be expected to change drastically with alteration of adenylate energy charge (Karl \& Holm-Hansen, 1978) and any differences in chemistry between the size fractions might introduce errors into the internal standard corrections for ATP and ETS measurements (Jones \& Simon, 1979). The criteria for acceptability were the determination of levels which differed significantly from the detection limits of the methods, the absence of excessive quenching of internal standards, and time response curves which did not deviate materially from the theoretical curve. Such results were obtained with ETS determinations of Windermere samples and ATP analyses of 
Table 4. Zoobenthos of littoral and profundal sediment cores from Blelham Tarn and the South Basin of Windermere in April 1979

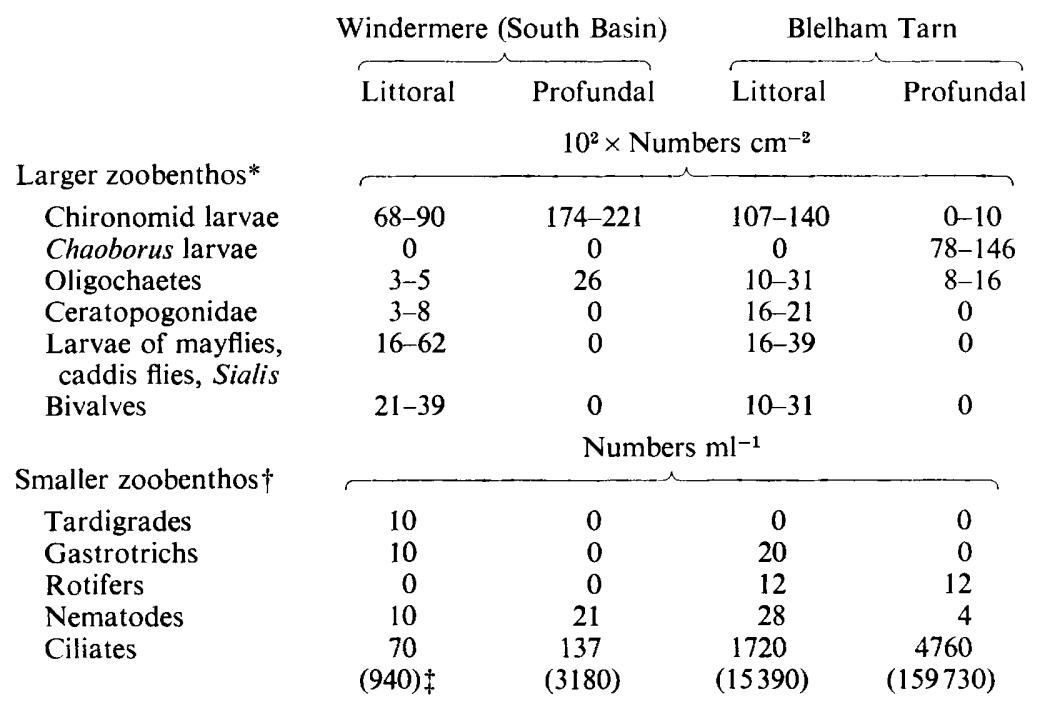

* The population of the top $10 \mathrm{~cm}$ of sediment in each core was separated and counted; the range of values from three cores is presented.

+ The surface $4 \mathrm{~cm}$ of sediment was diluted and counted in a suitable chamber.

$\ddagger$ Values in parentheses are numbers $(\mathrm{g} \text { dry wt) })^{-1}$.

Blelham Tarn sediments. In all but one sample higher values were obtained in the profundal samples and in the smaller size fractions. The agreement with direct counts was not absolutely perfect and although a low ATP concentration was observed in the $<45 \mu \mathrm{m}$ fraction of the Blelham Tarn littoral sediment (corresponding to the low direct count in Table 3) a suspiciously high ATP value was obtained in this fraction from the profundal sample. The ETS activities of the $<45 \mu \mathrm{m}$ fraction in Windermere sediments did not agree with direct counts, a slightly higher value being obtained in the littoral sample. There can be little doubt, however, that the greater proportion of smaller particles, and the larger microbial population associated with them, contributed significantly to the higher population estimates and activity recorded in the profundal sediments. This does not imply that the particle size factor is of primary importance in controlling the microheterotrophs. There must also be a greater nutrient input into the profundal zone otherwise higher organic substrate concentrations would be expected in the interstitial water of the less active littoral sediments.

Grazing by benthic animals remained to be considered as a factor with potential influence on the microbial population. There is ample evidence in the literature that grazing of detritus by both protozoa (Fenchel, 1972; Fenchel \& Jørgensen, 1977) and larger invertebrates (Fenchel \& Jørgensen, 1977; Hargrave, 1970, 1976) stimulates microbial activity. Examination of the cores analysed above showed marked differences in the zoobenthos (Table 4). There was a greater diversity of animals in the littoral zone of both lakes and, whereas larger numbers of chironomid larvae were found in the profundal zone of Windermere, the reverse was true of Blelham Tarn. The Chaoborus larvae were found only in the deeper sediments of Blelham Tarn. The ciliated protozoa were the most numerous of the smaller zoobenthos and were present in larger numbers in the profundal zones of both lakes. Apart from the consistent pattern of ciliate distribution, it would be unwise to conclude, from these data, that grazing by zoobenthos contributed to the stimulation in bacterial activity in the profundal zone, particularly since some of the animals listed in Table 4 (the Chaoborus larvae, some chironomids, the Ceratopogonidae, the larvae of Sialis and some 
caddis-fly larvae) are carnivores not detritivores. The larger zoobenthos may have contributed, however, to the particle size distribution in the sediments, which might be considered as having two origins. In the first place, the bulk of material deposited on littoral sediments is likely to be coarser (e.g. macrophyte detritus, leaf fall) than the finer algal remains which sediment into the profundal zone. Once it has reached the littoral sediment the material may then be processed by animals, and the smaller particles selectively resuspended by turbulence in the epilimnion. When these smaller particles enter the less turbulent hypolimnion, they may then sediment into the profundal zone. Thus the combined action of animal processing, resuspension and sedimentation may contribute to the particle size distribution observed in the sediments.

Systematic differences in the microbiology of littoral and profundal sediments have been demonstrated in both a deep mesotrophic lake and a shallow eutrophic lake. It is likely that available nutrients, sediment particle size distribution and animal grazing contributed, possibly in that order of importance, to these differences, but further experimental evidence will be required before the relative roles of these components can be assessed.

I am very grateful to B. M. Simon, J. S. Collis, S. Ellis and D. A. Nicholl who helped with the microbiological analyses, to E. Rigg who performed the inorganic chemical analyses, to T. I. Furnass who drew the figure and to Miss E. M. Evans who typed the script.

\section{REFERENCES}

BradFORD, M. M. (1976). A rapid and sensitive method for the quantitation of microgram quantities of protein utilizing the principle of proteindye binding. Analytical Biochemistry 72, 248-254.

Dick, M. W. (1971). The ecology of Saprolegniaceae in lentic and littoral muds with a general theory of fungi in the lake ecosystem. Journal of General Microbiology 65, 325-337.

Fenchel, T. (1972). Aspects of decomposer food chains in marine benthos. Verhandlungsbericht der Deutschen Zoologischen Gesellschaft, 65 Jahresversammlung 14, 14-22.

Fenchel, T. \& Jørgensen, B. B. (1977). Detritus food chains of aquatic ecosystems: the role of bacteria. Advances in Microbial Ecology 1, 1-58.

Finlay, B. J., Laybourn, J. \& Strachan, I. (1979). A technique for the enumeration of benthic ciliated protozoa. Oecologia 39, 375-377.

Hargrave, B. T. (1970). The effect of a depositfeeding amphipod on the metabolism of benthic microflora. Limnology and Oceanography 15, 21-30.

Hargrave, B. T. (1972). Aerobic decomposition of sediment and detritus as a function of particle surface area and organic content. Limnology and Oceanography 17, 583-596.

Hargrave, B. T. (1976). The central role of invertebrate faeces in sediment decomposition. Symposia of the British Ecological Society 17, 301-321.

HobBIE, J. E. \& Crawford, C. C. (1969). Bacterial uptake of organic substrate: new methods of study and application to eutrophication. Verhandlungen der Internationalen Vereinigung für theoretische und angewandte Limnologie 17,725-730.

JoNES, J. G. (1971). Studies on freshwater bacteria: factors which influence the population and its activity. Journal of Ecology 59, 593-613.

JoNes, J. G. (1979). Microbial activity in lake sedi- ments with particular reference to electrode potential gradients. Journal of General Microbiology 115, 19-26.

Jones, J. G. \& Simon, B. M. (1975a). An investigation of errors in direct counts of aquatic bacteria by epifluorescence microscopy, with reference to a new method for dyeing membrane filters. Journal of Applied Bacteriology 39, 317-329.

Jones, J. G. \& Simon, B. M. (1975b). Some observations on the fluorometric determination of glucose in freshwater. Limnology and Oceanography 20, 882-887.

JONES, J. G. \& SiMON, B. M. (1977). Increased sensitivity in the measurement of ATP in freshwater samples with a comment on the adverse effect of membrane filtration. Freshwater Biology. 7, 253-260.

Jones, J. G. \& Simon, B. M. (1979). The measurement of electron transport system activity in freshwater benthic and planktonic samples. Journal of Applied Bacteriology 46, 305-315.

Jones, J. G. \& Simon, B. M. (1980). Decomposition processes in the profundal region of Blelham Tarn and the Lund Tubes. Journal of Ecology (in the Press).

Jones, J. G., Orlandi, M. J. L. G. \& Simon, B. M. (1979). A microbiological study of sediments from the Cumbrian lakes. Journal of General Microbiology 115, 37-48.

Karl, D. M. \& Holm-Hansen, O. (1978). Methodology and measurement of adenylate energy charge ratios in environmental samples. Marine Biology 48, 185-197.

Kochert, G. (1978). Protein determination by dye binding. In Handbook of Phycological Methods: Physiological and Biochemical Methods, pp. 92-93. Edited by J. A. Hellebust \& J. S. Craigie. Cambridge: Cambridge University Press. 
Mackereth, F. J. H., Heron, J. \& Talling, J. F. (1978). Water analysis: some revised methods for limnologists. Freshwater Biological Association Scientific Publication no. 36.

Marshall, K. C. (1976). Interfaces in Microbial Ecology. Cambridge, Mass.: Harvard University Press.

Mortimer, C. H. (1942). The exchange of dissolved substances between mud and water in lakes. III and IV. Journal of Ecology 30, 147-201.

NoRTh, B. B. (1975). Primary amines in California coastal waters: utilization by phytoplankton. Limnology and Oceanography 20, 20-27.

OWENS, T. G. \& KING, F. D. (1975). The measurement of respiratory electron-transport system activity in marine zooplankton. Marine Biology 30, 27-36.

Udenfriend, S., Stein, S., Böhlen, P., Dairman, W., Leimgruber, W. \& Weigele, M. (1972). Fluorescamine: a reagent for assay of amino acids, peptides, proteins and primary amines in the picomole range. Science $178,871-872$.
Whitfield, M. (1969). $E_{h}$ as an operational parameter in estuarine studies. Limnology and Oceanography 14, 547-558.

Willoughby, L. G. (1961). The ecology of some lower fungi at Esthwaite Water. Transactions of the British Mycological Society 44, 305-332.

WilloughBy, L. G. (1965). Some observations on the location of fungal activity at Blelham Tarn. Hydrobiologia 25, 352-356.

WilloughBy, L. G. (1969). A study of the aquatic actinomycetes of Blelham Tarn. Hydrobiologia 34, 465-483.

WilloughBy, L. G. (1974). The ecology of lower freshwater phycomycetes in the tube experiment at Blelham Tarn. Veröffentlichungen des Instituts für Meeresforschung in Bremerhaven, Supplement 5, 175-195.

ZoBell, C. E. (1943). The effect of solid surfaces upon bacterial activity. Journal of Bacteriology 46, 39-56. 